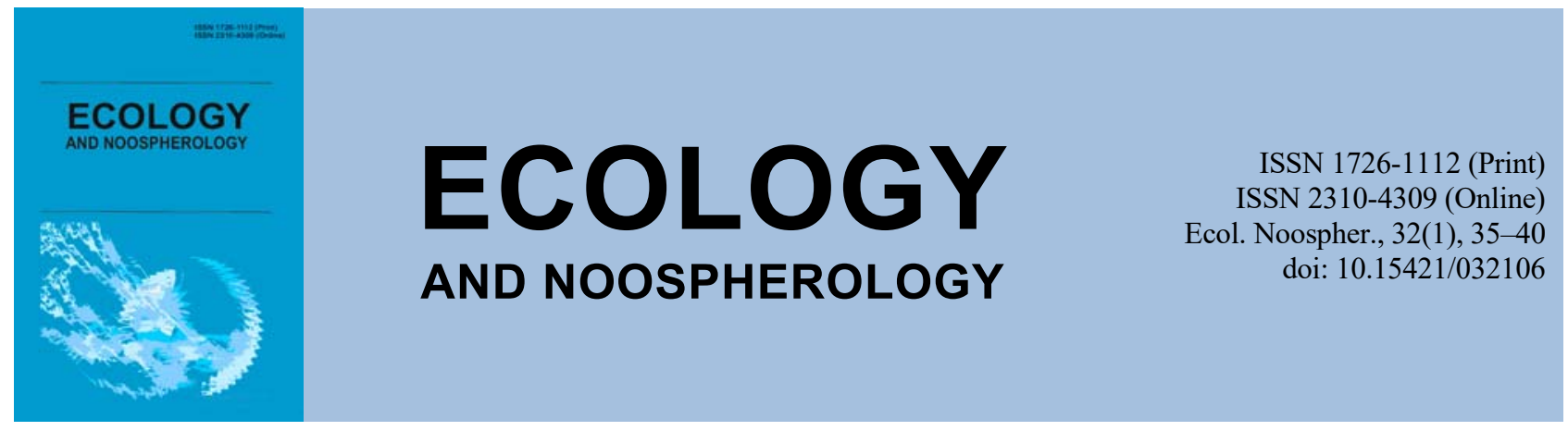

\title{
Spectral parameters of Robinia pseudoacacia L. seeds in technogenic conditions of urban environment
}

\author{
V. S. Fedenko \\ Oles Honchar Dnipro National University, Dnipro, Ukraine
}

Article info

Received 05.05.2021

Received in revised form

18.05.2021

Accepted 04.06.2021

Oles Honchar Dnipro

National University,

Gagarin Ave., 72, Dnipro,

49010, Ukraine.

Tel.: +38-096-531-01-84

E-mail:

opticlab.fedenko@gmail.com
Fedenko, V. S. (2021). Spectral parameters of Robinia pseudoacacia L. seeds in technogenic conditions of urban environment. Ecology and Noospherology, 32(1), 35-40. doi:10.15421/032106

Robinia pseudoacacia L. (black locust) is an invasive species with high activity in alien flora of Ukraine. Invasive potential of plants in unfavorable ecological conditions is due to the presence of adaptive mechanisms. One of the criteria for the invasive potential of foreign plants is considered to be seed productivity. For plants of black locust note a high level of seed productivity. However, it remains to be seen what factors ensure the formation of viable seeds in extreme environments. Among the factors that ensure the formation of viable plant seeds, note the barrier function of the seed coat relative to biotic and abiotic environmental factors. The physiological role of this protective barrier is realized due to the specific properties and component composition of the surface tissues of seeds. Among the metabolites with protective properties localized in the seed coat, consider proanthocyanidins (condensed tannins), which are formed during the biosynthesis of phenolic compounds. To objectively assess changes in the accumulation of proanthocyanidins in the seed coat, it is necessary to use non-destructive methods, because the isolation of these compounds destroys their native polymer structure. The influence of technogenic pollution of Dnipro city on the reflectance, colorimetric and fluorescent characteristics of Robinia pseudoacacia L. seeds is investigated in the work. Mature seeds of black locust were collected at monitoring sites in the Botanical Garden of Oles Honchar Dnipro National University (ecologically favorable zone) and at some points of linear roadside plantations of one of the main highways. It was found that the chronic effect of aerogenic pollutants on black locust plants caused an increased accumulation of proanthocyanidins in the seed coat, which may be due to changes in the biosynthesis of these compounds at the stage of oxidative polymerization of flavonoid subunits. Markers of this reaction of plants are the change of position and increase of intensity of maxima in the reflectance spectra of visible region, increase of value of dominant wavelength, decrease of conditional purity of color tone and colorimetric coefficients, increase of intensity of maxima in seed fluorescence spectra. The protective effect of these adaptive changes is associated with the strengthening of the barrier function of the seed coat to adverse environmental factors to maintain the viability of the seeds under the negative impact of technogenic pollution.

Keywords: Robinia pseudoacacia L.; seed; reflectance spectra; colorimetry; fluorescence; technogenic contamination

\section{Спектральні параметри насіння Robinia pseudoacacia L. у техногенних умовах урбосередовища}

\author{
В. С. Феденко
}

Дніпровський національний університет імені Олеся Гончара, Дніпро, Україна

Представлено результати дослідження впливу техногенного забруднення м. Дніпра на відбивальні, колориметричні та флуоресцентні характеристики насіння Robinia pseudoacacia L. Встановлено, що хронічна дія аерогенних полютантів на рослини робінії звичайної спричиняла підвищене накопичення проантоціанідинів у насіннєвій оболонці, що може бути 
наслідком змін біосинтезу цих сполук на стадії окиснювальної полімеризації флавоноїдних субодиниць. Маркерними ознаками цієї реакції відповіді рослин є зміна положення і зростання інтенсивності максимумів у спектрі відбиття видимого діапазону, підвищення значення домінувальної довжини хвилі, зменшення умовної чистоти кольорового тону та колориметричних коефіцієнтів, збільшення інтенсивності максимумів у спектрах флуоресценції насіння. Захисний ефект цих адаптивних змін пов'язаний із підсиленням бар'єрної функції насіннєвої оболонки до несприятливих чинників середовища для збереження життєздатності насіння за умов негативного впливу техногенного забруднення.

Ключові слова: Robinia pseudoacacia L.; насіння; спектри відбиття; колориметрія; флуоресценція; техногенне забруднення

\section{Вступ}

Робінія звичайна Robinia pseudoacacia L. - інвазійний вид із високою активністю у процесі адвентизації флори України (Protopopova, Shevera, 2019). Інвазії $R$. pseudoacacia спричиняють суттєвий вплив на різні компоненти екосистем (Gorban, Huslystyi, 2018; Lazzaro et al., 2018). При цьому інвазійний потенціал рослин у несприятливих екологічних умовах обумовлений наявністю адаптивних механізмів. Для $R$. pseudoacacia в урбоекосистемах вплив комплексу біотичних і абіотичних факторів призводить до підвищення акумуляції металів у листках (Gratani et al., 2021), зниження життєвого стану рослин у лінійних пришляхових насадженнях порівняно із парковими зонами (Wilkaniec et al., 2021).

Одним із критеріїв інвазійного потенціалу чужорідних рослин вважають насіннєву продуктивність (Zavialova, 2019). Для рослин робінії звичайної відзначають високий рівень насіннєвої продуктивності (Nicolescu et al., 2020). Однак залишається поза увагою з'ясування проблеми, за рахунок яких чинників забезпечується формування життєздатного насіння в екстремальних умовах середовища. Разом с тим, за даними Barrett et al. (2008), еволюційні модифікації репродуктивних систем у мінливих умовах експансії підсилюють інвазійну активність рослин. Цей факт нещодавно підтверджений результатами Bouteiller et al. (2021) про підвищену здатність до проростання насіння $R$. pseudoacacia, що сформоване в інвазійних популяціях Європи відносно природних популяцій в Америці.

Серед чинників, які забезпечують формування життездатного насіння рослин, відзначають бар'єрну функцію насіннєвої оболонки відносно біотичних і абіотичних чинників середовища (Smykal et al., 2014). Фізіологічна роль цього захисного бар'єру реалізується завдяки специфічним властивостям i компонентному складу поверхневих тканин насіння (Moise et al., 2005). Серед метаболітів з протекторними властивостями, що локалізовані у насіннєвій оболонці, розглядають проантоціанідини (конденсовані таніни), які утворюються у процесі біосинтезу фенольних сполук (Lepiniec et al., 2006). Захисний ефект проантоціанідинів обумовлений антиоксидантними, антибактеріальними та антимутагенними властивостями (Dixon et al., 2005). Встановлено також антимікробну активність екстракту низькомолекулярних метаболітів із перикарпію деяких деревних рослин (у тому числі $R$. pseudoacacia), що розглядають як один із факторів стійкості сіянців до фітопатогенних мікроорганізмів (Likhanov et al., 2019). Разом 3 тим адаптивна роль цих сполук при формуванні насіння за умов техногенного забруднення середовища не з'ясована. У зв'язку з цим слід зазначити, що дослідження адвентивних рослин за умов забрудненого середовища розглядають як один із сучасних пріоритетних напрямів інвазійної екології (Pyšek et al., 2020).

Для об'єктивної оцінки змін накопичення проантоціанідинів у насіннєвій оболонці необхідно використовувати неруйнівні методи, оскільки при виділенні цих сполук відбувається руйнування їх нативної полімерної будови (Ajila et al., 2011). У зв'язку з тим що пігментація насіння пов'язана із здатністю проантоціанідинів поглинати світло видимого діапазону, одними із неруйнівних методів їх дослідження можуть бути спектроскопія відбиття (Tigabu et al., 2005), колориметрія (Chukwumah et al., 2009) та флуоресцентний аналіз (Barboza da Silva et al., 2021). Однак спектральні характеристики насіння $R$. pseudoacacia дотепер не досліджені. Оскільки заключний етап біосинтезу проантоціанідинів пов'язаний із ступенем окиснювальної полімеризації флавоноїдних субодиниць (Lepiniec et al., 2006), а стресорні чинники індукують підвищений рівень активних форм кисню (Kranner et al., 2010), слід висловити гіпотезу, згідно 3 якою вплив антропогенного навантаження може призвести до змін пігментації насіннєвої оболонки, що може бути встановлено за допомогою спектральних методів.

Мета дослідження - провести порівняльний аналіз спектральних характеристик насіння робінії звичайної, яке сформоване за екологічно сприятливих та техногенних умов.

\section{Матеріали та методи досліджень}

Об'єкт дослідження - робінія звичайна Robinia pseudoacacia L. як поширений вид деревних рослин у флорі м. Дніпра (Karmyzova, Baranovsky, 2020). Стигле насіння відбирали на моніторингових ділянках у Ботанічному саду Дніпровського національного університету імені Олеся Гончара (екологічно сприятлива зона, умовний контроль) та в окремих точках лінійних пришляхових насаджень однієї з основних автомагістралей м. Дніпра (проспект Богдана Хмельницького) при аеротехногенному забрудненні викидами автотранспорту. Дослідну ділянку обрано 3 урахуванням результатів обстеження, які підтвердили суттєвий вплив антропогенного навантаження на життєвий стан рослин робінії звичайної у цій техногенній зоні (Ponomaryova, 2018).

Для діагностики накопичення фенольних метаболітів у покривних тканинах суцільного насіння досліджували відбивальні, колориметричні та флуоресцентні параметри. Для підготовки зразків до вимірювань спектральних параметрів користувались стандартними тримачами твердих препаратів до використаних оптичних приладів за умов повного покриття поверхні.

Спектри відбиття насіння отримували в діапазоні 350 800 нм на спектрофотометрі Specord M40 (Німеччина), додатково обладнаному приставкою 3 фотометричною кулею і касетою «Data Handling I» для математичної обробки результатів вимірювання, що дозволило проводити згладжування спектральних кривих із виключенням випадкових шумових піків (Fedenko, 2008). Корекцію 100\%-ї лінії проводили за стандартом MgO, оптичної нульової точки - за стандартом чорного порожнистого тіла. Інтенсивність спектрів відбиття наводили в одиницях абсорбції. Диференційний спектр обчислювали за різницею абсорбції $\Delta \mathrm{A}$ при відповідній довжині хвилі у спектрах відбиття дослідного i контрольного зразків.

Для колориметричних вимірювань використовували спектрофотометр Specord M 40 з іншою касетою для математичної обробки «Color Measurement» 3 метою визначення координат кольору $(X, Y, Z)$, координат кольоровості $(x, y)$ та колориметричних коефіцієнтів $\left(L^{*}\right.$, $\left.a^{*}, b^{*}\right)$ препаратів. Значення домінувальної довжини хвилі $\lambda_{d}$ i умовної чистоти кольорового тону $P_{e}$ знаходили графічним методом за кольоровим графіком згідно 3 
рекомендаціями, описаними в роботі Fedenko et al. (2017). Кольорові характеристики наводили в колориметричних системах XYZ та CIE $L * a * b *$. На основі значень колориметричних коефіцієнтів обчислювали значення кольоровості $C^{*}$, кольорового тону $h$, кольорової відмінності $\Delta E^{*}$ між насінням із техногенної зони відносно насіння з екологічно сприятливої зони, а також розподіл цієї інтегральної величини на складові відмінності за яскравістю $\Delta L^{*}$, кольоровістю $\Delta C^{*}$ та кольоровим тоном $\Delta H^{*}$.

Спектри флуоресценції вимірювали у діапазоні 420650 нм (довжина хвилі збудження - 400 нм) на спектрофлуориметрі MPF-4 (Японія) згідно 3 рекомендаціями (Fedenko, Struzhko, 1996).

Похибка вимірювань спектральних параметрів не перевищувала $5 \%$. Статистичну обробку експериментальних даних проводили 3 5\%-ним рівнем значущості.

\section{Результати досліджень}

У спектрах відбиття насіння з екологічно сприятливої зони спостерігалась широка смуга без чіткого розділення максимумів при 365, 395 і 420 нм із зіставними значеннями інтенсивності (рис. 1). Такий характер кривої у спектрі відбиття - результат взаємодії випромінюванням видимого діапазону із сполуками, які мають хромофорні групи та локалізовані у насіннєвій оболонці. Серед цих сполук переважають проантоціанідини - група олігомерних метаболітів із різним ступенем полімеризації мономерних флавоноїдних субодиниць (Smykal et al., 2014). Структурні особливості цих сполук зумовлюють тип спектральної кривої без чіткого прояву максимумів, що характерно саме для полімерних хромофорних систем проантоціанідинів у покривних тканинах насіння (Troshchynska et al., 2019). Додаткове ускладнення профілю спектральної смуги може відбуватись за рахунок суперпозиції із максимумами мономерних флавоноїдів - метаболічних попередників проантоціанідинів (Sanz et al., 2011). У зв'язку з цим слід зазначити, що фітохімічний склад насіннєвої оболонки насіння $R$. pseudoacacia не досліджено, а для серцевини дерева цього виду встановлено значну гетерогенність фенольних сполук, серед яких ідентифіковано дімерний олігомер проробінетидин, а серед флавоноїдів, які можуть бути задіяні у процесі олігомеризації, основними компонентами є дігідроробінетин та робінетин (Sanz et al., 2011). При цьому для робінетину встановлено основний максимум поглинання при 366 нм (Destandau et al., 2016),

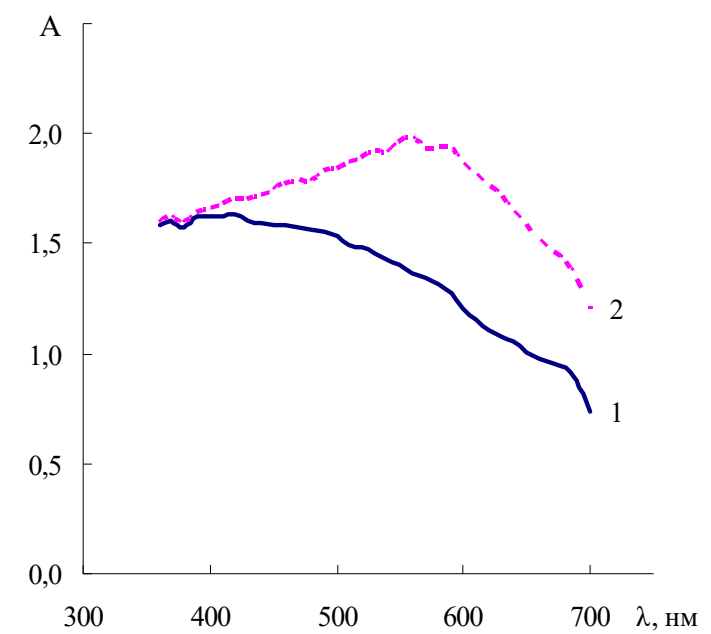

Рис. 1. Спектри відбиття насіння Robinia pseudoacacia L.: 1 - екологічно сприятлива зона; 2 - техногенна зона. що майже збігається із положенням короткохвильового максимуму (365 нм) у спектрі відбиття насіння із контрольної зони (рис. 1), підтверджуючи накопичення мономерних флавоноїдних метаболітів у поверхневих тканинах насіння.

Для зразка із техногенної зони відзначено підвищення інтенсивності і батохромне зміщення смуги із появою додаткових високоінтенсивних максимумів при 530, 555 і 580 нм у спектрі відбиття (рис. 1). Оптична густина найінтенсивнішого максимуму при 550 нм збільшена на $45,6 \%$ для насіння із техногенної зони порівняно із контрольним зразком. Такі особливості відбивальних характеристик дослідного зразка можуть бути обумовлені зміною рівня накопичення, складу та підвищенням ступеня полімеризації флавоноїдних субодиниць, оскільки внаслідок цього процесу утворюються більш спряжені хромофорні системи.

Для підтвердження відмінностей відбивальних характеристик зразків із різних моніторингових зон додатково використано методичний прийом диференційної спектрофотометрії. У результаті розрахунку різниці між спектральними кривими дослідного i контрольного зразків отримано диференційний спектр, у якому встановлена наявність максимумів при 560 і 610 нм у довгохвильовому діапазоні (рис. 2). Цей факт підтвердив, що основним чинником, який створюе відмінність фітохімічного складу насіннєвої оболонки зразка із техногенної зони, може бути підвищена ступінь полімеризації флавоноїдних метаболітів.

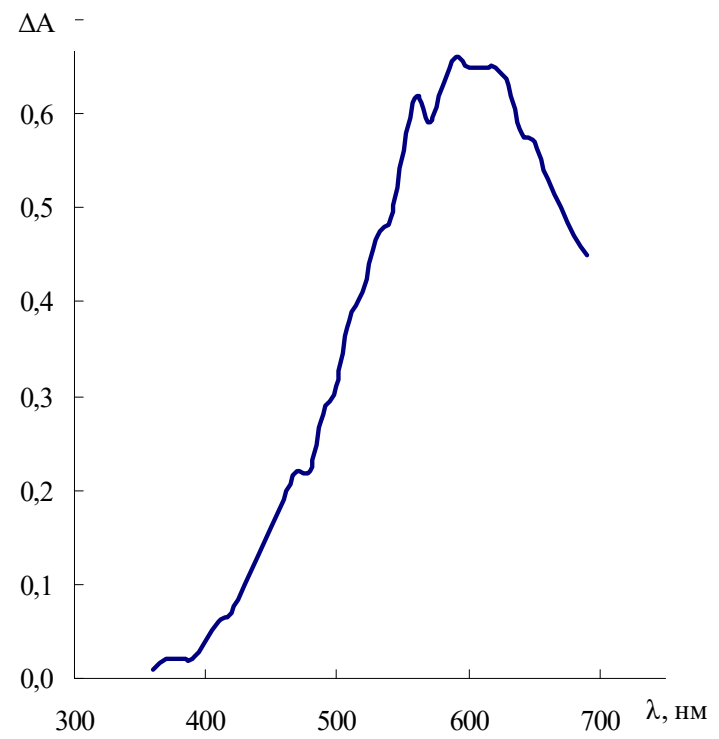

Pис. 2. Диференційний спектр відбиття насіння Robinia pseudoacacia L. із техногенної зони відносно насіння з екологічно сприятливої зони

Оскільки саме локалізація проантоціанідинів у поверхневих тканинах $є$ основним чинником забарвлення насіннєвої оболонки (Troshchynska et al., 2019), підвищення рівня накопичення цих сполук обумовлює варіабельність колориметричних параметрів насіння залежно від умов зростання рослин (табл. 1). Так, збільшення величини домінувальної довжини хвилі $\lambda_{\mathrm{d}}$ на 34,3 нм (табл. 1) пояснює підвищення насиченості брунатного кольору насіння із техногенної зони, що відповідало гіперхромному ефекту i батохромному зміщенню смуги у спектрі відбиття (рис. 1). При цьому відзначено зменшення умовної чистоти кольорового тону

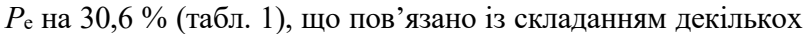
кольорових стимулів при підвищенні гетерогенності складу поліфенольних пігментів у насінні із техногенної зони. Підвищене накопичення проантоціанідинів при 
антропогенному навантаженні призвело до зменшення на 35,0 \% величини коефіцієнта яскравості $L$ * як інтегрального показника світлого потоку, що відбивається від насіннєвої оболонки, а також значень колориметричних коефіцієнтів $a^{*}$ i $b^{*}$, чутливих до змін кольорового тону (на 47,7 i 130,1\% відповідно) (табл. 1). Навпроти, значення кольоровості $C^{*}$ та кольорового тону $h$ для дослідного зразка підвищено на 81,4 і 20,4 \% відповідно (табл. 1). 3 огляду на встановлену тенденцію підвищення кольорового тону $h$ насіння за умов техногенного навантаження, слід відзначити підтверджену раніше позитивну корелятивну залежність цього показника iз умістом проантоціанідинів та антиоксидантною активністю насіння (Chukwumah et al., 2009). Крім того, за даними Elessawy et al. (2021), підвищення насиченості кольорового тону насіннєвої оболонки пов'язане із збільшенням накопичення поліфенольних сполук, що призводить до зростання метал-хелатуючої здатності.

\section{Таблиця 1}

Колориметричні характеристики насіння Robinia pseudoacacia L. iз різних моніторингових зон

\begin{tabular}{ccc}
\hline $\begin{array}{c}\text { Колориметричний } \\
\text { параметр }\end{array}$ & $\begin{array}{c}\text { Екологічно } \\
\text { сприятлива зона }\end{array}$ & $\begin{array}{c}\text { Техногенна } \\
\text { зона }\end{array}$ \\
\hline$\lambda d$, нм & 593,1 & 627,4 \\
$P e, \%$ & 45,5 & 14,9 \\
$L^{*}$ & 28,9 & 18,8 \\
$a^{*}$ & 7,3 & 3,8 \\
$b^{*}$ & $-9,00$ & $-20,71$ \\
$C^{*}$ & 11,6 & 21,1 \\
$h$ & 140,8 & 169,5 \\
\hline
\end{tabular}

Використовуючи прийом диференційної колориметрії, розраховано кольорові відмінності у пігментації насіння із техногенної та екологічно сприятливої зон (рис. 3). При цьому встановлено зіставний внесок в інтегральну величину $\Delta E^{*}$ складових відмінностей за яскравістю $\Delta L^{*}$, кольоровістю $\Delta C^{*}$ та кольоровим тоном $\Delta H^{*}$.

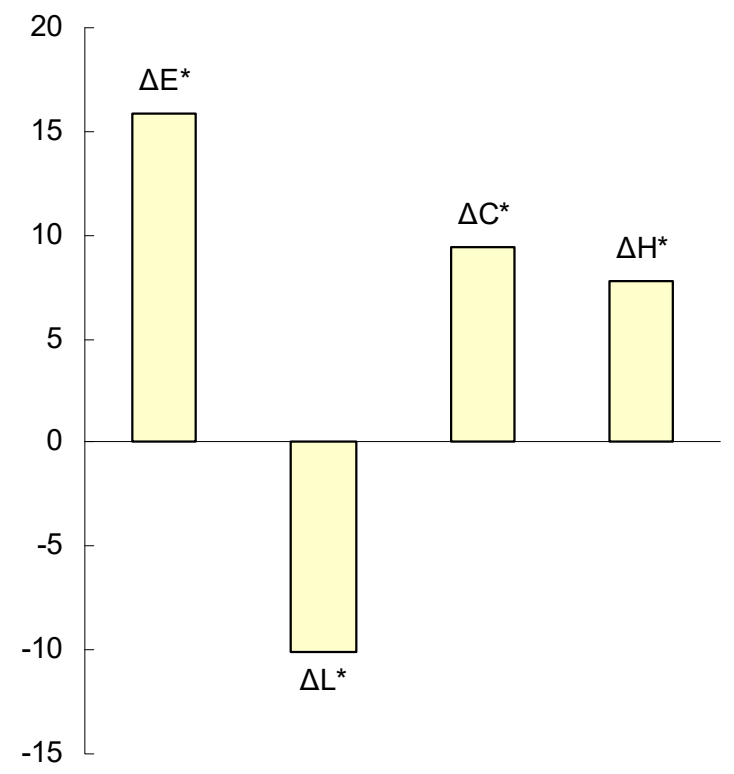

Pис. 3. Кольорові відмінності насіння Robinia pseudoacacia L. iз техногенної зони відносно насіння з екологічно сприятливої зони

3 урахуванням флуоресцентних властивостей фенольного метаболіту, який виділено із сировини $R$. pseudoacacia (Bostyn et al., 2018), нами досліджено спектри флуоресценції покривних тканин насіння. При збудженні світлом із довжиною хвилі 400 нм в спектрах флуоресценції зразків із обох моніторингових зон спостерігались максимуми при 463 та 495 нм (рис. 4), які можуть бути віднесені до флуорофорів флавоноїдної природи (Donaldson, 2020). Інтенсивність першого та другого максимумів збільшувалась відповідно на 64 та $68 \%$ для дослідного зразка, що свідчило про підвищене накопичення цих сполук у насіннєвій оболонці за умов техногенного забруднення. Слід додати, що раніше нами підтверджена можливість використання флуоресцентного методу для діагностики змін накопичення протекторних сполук фенольної природи у насінні злакових культур за умов антропогенної радіонуклідної аномалії (Fedenko, Struzhko, 1996).

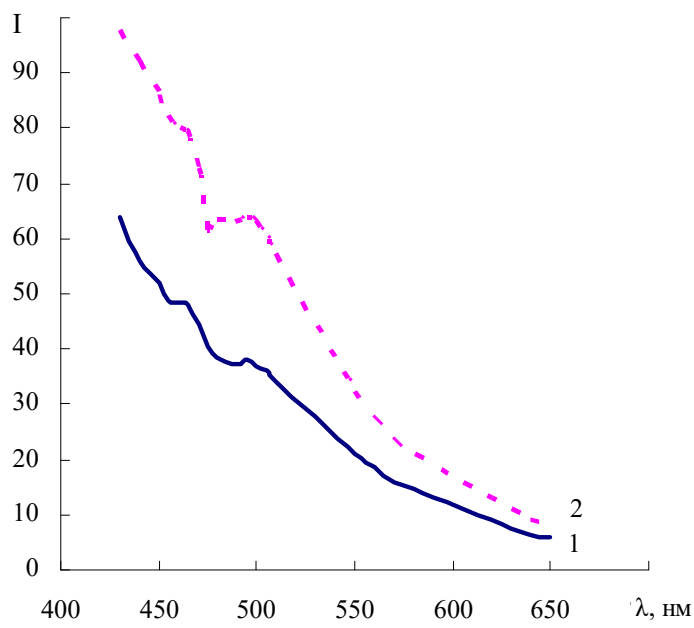

Pис. 4. Спектри флуоресценції насіння Robinia pseudoacacia $\mathrm{L}$ :

1 - екологічно сприятлива зона; 2 - техногенна зона

Аналізуючи отримані результати, слід зазначити, що встановлена нами тенденція підвищеного накопичення проантоціанідинів у насіннєвій оболонці $R$. pseudoacacia при аерогенному навантаженні погоджується із результатами щодо індукції біосинтезу фенольних сполук для рослин цього виду за токсичної дії металів (Kim et al., 2020), а також за умов комбінованого впливу цих полютантів та підвищеної температури (Zhao et al., 2016) або підвищеного рівня $\mathrm{CO}_{2}$ в атмосфері (Zhang et al., 2021). Такі адаптивні зміни відповідають неспецифічній реакції рослин - метал/металоїд-індукованому підвищенню акумуляції фенольних сполук (Fedenko et al., 2020). Крім того, захисний ефект проантоціанідинів проявляється в УФпротекторній, антиоксидантній, антифунгіцидній активності (Dixon, Sarnala, 2020) та метал-хелатуючій здатності (Elessawy et al., 2021). Протекторну функцію проантоціанідинів до комплексу біотичних та абіотичних факторів слід розглядати як один із чинників високої інвазійної активності $R$. pseudoacacia та їі ефективності для фіторемедіації забруднених територій в екстремальних умовах середовища.

Отримані результати розширюють уявлення щодо діагностичної значущості вторинних метаболітів фенольної природи в індикації стану деревних рослин в урбофітоценозах, а також можуть бути використані для подальшої розробки концепції стресу для насіння рослин (Kranner et al., 2010).

Використані нами спектроскопія відбиття у видимому діапазоні, колориметрія та флуоресценція розширюють методичну основу прижиттєвої діагностики адаптивних змін рослин i відповідають сучасному напряму дослідження функціонального стану та ідентифікації деревних культур із використанням комплексу неруйнівних спектральних методів (Pang et al., 2021). 


\section{Висновки}

Установлено, що хронічна дія аерогенних полютантів на рослини робінії звичайної спричиняла підвищене накопичення проантоціанідинів у насіннєвій оболонці, що може бути наслідком змін біосинтезу цих сполук на стадії окиснювальної полімеризації флавоноїдних субодиниць. Маркерними ознаками цієї реакції відповіді рослин при формуванні поверхневих тканин рослин $є$ зміна положення і зростання інтенсивності максимумів у спектрі відбиття видимого діапазону, підвищення значення домінувальної довжини хвилі, зменшення умовної чистоти кольорового тону та колориметричних коефіцієнтів, збільшення інтенсивності максимумів у спектрах флуоресценції. Захисний ефект цих адаптивних змін пов'язаний із підсиленням бар'єрної функції насіннєвої оболонки до несприятливих чинників середовища для збереження життездатності насіння за умов негативного впливу техногенного забруднення.

\section{References}

Ajila, C. M., Brar, S. K., Verma, M., Tyagi, R. D., Godbout, S., Valero, J. R. (2011). Extraction and analysis of polyphenol: recent trends. Critical Rev. Biotechnol., 31(3), 227-249.

Barboza da Silva, C., Oliveira, N. M., de Carvalho, M. E. A., de Medeiros, A. D., de Lima Nogueira, M., Dos Reis, A. R. (2021). Autofluorescence-spectral imaging as an innovative method for rapid, non-destructive and reliable assessing of soybean seed quality. Scientific reports, 11(1), $\underline{1-12 .}$

Barrett, S. C., Colautti, R. I., Eckert, C. G. (2008). Plant reproductive systems and evolution during biological invasion. Mol. Ecol., 17(1), 373-383.

Bostyn, S., Destandau, E., Charpentier, J. P., Serrano, V., Seigneuret, J. M., Breton, C. (2018). Optimization and kinetic modelling of robinetin and dihydrorobinetin extraction from Robinia pseudoacacia wood. Ind. Crops Prod., 126, 22-30.

Bouteiller, X. P., Moret, F., Ségura, R., Klisz, M., Martinik, A., Monty, A., Pino, J., van Loo, M., Wojda, T., Porté, A. J., Mariette, S. (2021). The seeds of invasion: enhanced germination in invasive European populations of black locust (Robinia pseudoacacia L.) compared to native American populations. Plant Biol., 23 (6), 1006-1017.

Chukwumah, Y., Walker, L. T., Verghese, M. (2009). Peanut skin color: a biomarker for total polyphenolic content and antioxidative capacities of peanut cultivars. Int. J. Mol. Sci., 10, 4941-4952.

Destandau, E., Charpentier, J. P., Bostyn, S., Zubrzycki, S., Serrano, V., Seigneuret, J. M., Breton, C. (2016). Gramscale purification of dihydrorobinetin from Robinia pseudoacacia L. wood by centrifugal partition chromatography. Separations, 3(3), 23.

Dixon, R. A., Sarnala, S. (2020). Proanthocyanidin biosynthesis - A matter of protection. Plant physiol., 184(2), 579-591.

Dixon, R. A., Xie, D.-Y., Sharma, S. B. (2005). Proanthocyanidins - a final frontier in flavonoid research? New Phytol., 165, 9-28.

Donaldson, L. (2020). Autofluorescence in plants. Molecules, 25(10), 2393.

Elessawy, F. M., Vandenberg, A., El-Aneed, A., Purves, R. W. (2021). An untargeted metabolomics approach for correlating pulse crop seed coat polyphenol profiles with antioxidant capacity and iron chelation ability. Molecules, 26(13), 3833.

Fedenko, V. S. (2008). Tsianidyn yak endohennyy khelator ioniv metaliv u korenyakh prorostkiv kukurudzy [Cyanidin as endogenous chelator of metal ions in maize seedling roots]. Ukrainskyi Biokhimichnyi Zhurnal, 80(1), 102-106 (in Ukrainian).

Fedenko, V. S., Landi, M., Shemet, S. A. (2017). Detection of nickel in maize roots: A novel nondestructive approach by reflectance spectroscopy and colorimetric models. Ecological indicators, 82, 463-469.

Fedenko, V. S., Shemet, S. A., Guidi, L., Landi, M. (2020). Metal/metalloid-induced accumulation of phenolic accumulation in plants. In: M. Landi, S. A. Shemet, V. S. Fedenko (eds.). Metal toxicity in higher plants. Nova Science Publishers, 67-115.

Fedenko, V. S., Struzhko, V. S. (1996). Soderzhaniye fenol'nykh soyedineniy zlakovykh kul'tur $\mathrm{v}$ usloviyakh antropogennoy radionuklidnoy anomalii [Content of phenol compounds of cereals under anthropogenic radionuclide anomaly]. Fiziologiya i Biokhimiya Kul'turnykh Rastenij, 28(4), 273-281 (in Russian).

Gorban, V. A., Huslystyi, A. O. (2018). Deyaki osoblyvosti vplyvu nasadzhen' Robinia pseudoacacia L. na grunty $\mathrm{v}$ posushlyvykh umovakh [Some features of the influence of Robinia pseudoacacia L. on soils in arid conditions]. Ecology and Noospherology, 29(1), 47-51 (in Ukrainian).

Gratani, L., Vasheka, O., Bigaran, F. (2021). Metal accumulation capability by Platanus acerifolia (Aiton) Willd., Ailantus altissima (Mill.) Swingle, Robinia pseudoacacia L. and Quercus ilex L., largely distributed in the city of Rome. Am. J. Plant Sci., 12(01), 163.

Karmyzova, L., Baranovsky, B. (2020). Flora of the Dnipro city. Publishing House "Baltija Publishing". 120 p.

Kim, N. S., Sathasivam, R., Chun, S. W., Youn, W. B., Park, S. U., Park, B. B. (2020). Biosynthesis of phenylpropanoids and their protective effect against heavy metals in nitrogenfixing black locust (Robinia pseudoacacia). Trop. J. Pharm. Res., 19(5), 1065-1072.

Kranner, I., Minibayeva, F. V., Beckett, R. P., Seal, C. E. (2010). What is stress? Concepts, definitions and applications in seed science. New Phytol., 188, 655-673.

Lazzaro, L., Mazza, G., d'Errico, G., Fabiani, A., Giuliani, C., Inghilesi, A. F., Lagomarsino, A., Landi, S., Lastrucci, L., Pastorelli, R., Roversi, P. F., Torrini, G., Tricarico, E., Foggi, B. (2018). How ecosystems change following invasion by Robinia pseudoacacia: Insights from soil chemical properties and soil microbial, nematode, microarthropod and plant communities. Sci. Total Environ., 622-623, 1509-1518.

Lepiniec, L., Debeaujon, I., Routaboul, J.-M., Baudry, A.. Pourcel, L., Nesi, N., Caboche, M. (2006). Genetics and biochemistry of seed flavonoids. Annu. Rev. Plant Biol., 57, 405-430.

Likhanov, A. F., Bilous, S. Yu., Borodai, V. V. (2019). Antymikrobna aktyvnist' vtorynnykh metabolitiv perykarpiyiv deyakykh vydiv derevnykh roslyn [Antimicrobial activity of pericarp secondary metabolites of some species of woody plants]. Lisove i sadovo-parkove hospodarstvo, 15, 1-13 (in Ukrainian).

Moise, J. A., Han, S., Gudynaite-Savitch, L., Johnson, D. A., Miki, B. L. A. (2005). Seed coats: structure, development, composition and biotechnology. In Vitro Cell. Dev. Biol. Plant, 41, 620-644.

Nicolescu, V. N., Rédei, K., Mason, W. L., Vor, T., Pöetzelsberger, E., Bastien, J. C., Brus, R., Benčat', T., Đodan, M., Cvjetkovic, B., Andrašev, S., La Porta, N., Lavnyy, V., Mandžukovski, D., Petkova, K., Roženbergar, D., Wasik, R., Mohren, G. M. J., Monteverdi, M. C., Musch, B., Klisz, M., Perić, S., Keça, L., Bartlett, D., Hernea, C., Pástor, M. (2020). Ecology, growth and management of black locust (Robinia pseudoacacia L.), a non-native species integrated into European forests. J. For. Res., 31(4), 1081-1101.

Pang, L., Wang, J., Men, S., Yan, L., Xiao, J. (2021). Hyperspectral imaging coupled with multivariate methods for seed vitality estimation and forecast for Quercus 
variabilis. Spectrochim. Acta A: Mol. Biomol. Spectrosc., 245, 118888 .

Ponomaryova, O. A. (2018). Bioriznomanittya ta zhytyevyy stan liniynykh pryshlyakhovykh nasadzhen' m. Dnipro (na prykladi prospektu im. B. Khmel'nyts'koho) [Biodiversity and living conditions of linear roadside plantations of Dnipro (on the example of B. Avenue Khmelnytsky]. Nauka. Molod'. Ekolohiya-2018: za materialamy KHIV-yi Vseukrayins'koyi naukovo-praktychnoyi konferentsiyi studentiv, aspirantiv ta molodykh vchenykh (m. Zhytomyr, 17 travnya 2018 roku). Zhytomyr, ZHNAU, 179-183 (in Ukrainian).

Protopopova, V. V., Shevera, M. V. (2019). Invaziyni vydy u flori Ukrayiny. I. Hrupa vysoko aktyvnykh vydiv [Invasive species in the flora of Ukraine. I. The group of highly active species]. Geo \& Bio, 17, 116-135 (in Ukrainian).

Pyšek, P., Hulme, P. E., Simberloff, D., Bacher, S., Blackburn, T. M., Carlton, J. T., Dawson, W., Essl, F., Foxcroft, L. C., Genovesi, P., Jeschke, J. M., Kühn, I., Liebhold, A. M., Mandrak, N. E., Meyerson, L. A., Pauchard, A., Pergl, J., Roy, H. E., Seebens, H., van Kleunen, M., Vilà, M., Wingfield, M. J., Richardson, D. M. (2020). Scientists' warning on invasive alien species. Biol. Rev., 95(6), 1511-1534.

Sanz, M., Fernandez de Simon, B., Esteruelas, E., Munoz, A. M., Cadahía, E., Hernandez, T., Estrella, I., Pinto, E. (2011). Effect of toasting intensity at cooperage on phenolic compounds in acacia (Robinia pseudoacacia) heartwood. J. Agric. Food Chem., 59(7), 3135-3145.

Smykal, P., Vernoud, V., Blair, M. W., Soukup, A., Thompson, R. D. (2014). The role of the testa during development and in establishment of dormancy of the legume seed. Front. Plant Sci., 5, 1-19.

Tigabu, M., Oden, P.C., Lindgren, D. (2005). Identification of seed sources and parents of Pinus sylvestris L. using visible-near infrared reflectance spectra and multivariate analysis. Trees, 19, 468-476.

Troshchynska, Y., Bleha, R., Kumbarová, L., Sluková, M., Sinica, A., Štětina, J. (2019). Discrimination of flax cultivars based on visible diffusion reflectance spectra and colour parameters of whole seeds. Czech J. Food Sci., 37(3), 199-204.

Wilkaniec, A., Borowiak-Sobkowiak, B., Irzykowska, L., Breś, W., Świerk, D., Pardela, Ł., Durak, R., Środulska-Wielgus, J., Wielgus, K. (2021). Biotic and abiotic factors causing the collapse of Robinia pseudoacacia L. veteran trees in urban environments. PLoS ONE, 16(1), e0245398.

Zavialova, L. (2019). Ohlyad metodiv doslidzhennya adventyvnykh roslyn [A review of methods of investigation of alien plant species]. Geo \& Bio, 18, 64-76 (in Ukrainian).

Zhang, C., Jia, X., Zhao, Y., Wang, L., Cao, K., Zhang, N., Gao, Y., Wang, Z. (2021). The combined effects of elevated atmospheric $\mathrm{CO}_{2}$ and cadmium exposure on flavonoids in the leaves of Robinia pseudoacacia L. seedlings. Ecotoxicol. Environ. Saf., 210, 111878.

Zhao, Y. H., Jia, X., Wang, W. K., Liu, T., Huang, S. P., Yang, M. Y. (2016). Growth under elevated air temperature alters secondary metabolites in Robinia pseudoacacia L. seedlings in $\mathrm{Cd}$-and $\mathrm{Pb}$-contaminated soils. Sci. Total Environ., 565, 586-594. 